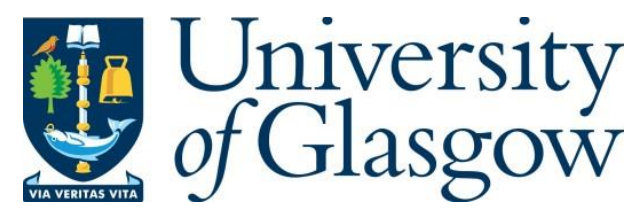

Beirne, M., Hurrell, S. and Wilson, F. (2019) Mobilising for equality?

Understanding the impact of grass roots agency and third party representation.

Industrial Relations Journal, 50(1), pp. 41-56.

There may be differences between this version and the published version. You are advised to consult the publisher's version if you wish to cite from it.

This is the peer reviewed version of the following article Beirne, M., Hurrell, S. and Wilson, F. (2019) Mobilising for equality? Understanding the impact of grass roots agency and third party representation. Industrial Relations Journal, 50(1), pp. 4156, which has been published in final form at http://dx.doi.org/10.1111/irj.12237. This article may be used for non-commercial purposes in accordance with Wiley Terms and Conditions for Self-Archiving.

http://eprints.gla.ac.uk/179983/

Deposited on: 6 March 2019

Enlighten - Research publications by members of the University of Glasgow http://eprints.gla.ac.uk 
Published in the Industrial Relations Journal 10 ${ }^{\text {th }}$ February 2019

\title{
Mobilising for equality? Understanding the impact of grass roots agency and third- party representation
}

\author{
Martin Beirne, Scott Hurrell and Fiona Wilson
}

\begin{abstract}
Does mobilisation theory provide telling insights into the collective expression of gendered grievances? By analysing the dynamics of activism on pay inequality in the British local authority sector, this article offers a negative evaluation, calling for a deeper understanding of grassroots agency and third-party representation beyond the workplace.
\end{abstract}

\section{Introduction}

Last year marked the $20^{\text {th }}$ anniversary of the publication of John Kelly's influential 1998 book Rethinking Industrial Relations: Mobilisation, Collectivism and Long Waves. This proposed a logical framework for systematically analysing the conditions that together stimulate or curtail collective action. Building on Tilly's (1977) more general articulation of how social groups may engage in collective action, Kelly presented mobilisation theory as a means of understanding the shifting fortunes and progressive potential of organised labour. His approach to research on union organising and worker activism continues to attract critical attention, and was recently celebrated with a dedicated seminar at the University of Leeds and a special issue of Economic and Industrial Democracy (Gall and Holgate, 2018).

Moving away from Tilly's focus on mobilising economic resources to further group interests, Kelly aimed to unpack the social processes and dynamics of mobilisation, according pivotal significance to grievance and injustice. He stressed the importance of workers attributing injustice to employers (and occasionally governments) and forming a collective social identity in response. Mobilising processes also depend upon the leadership of union officials, however. According to the theory, and most of the literature that has developed around it, employee feelings of injustice are insufficient in themselves, and must be actively framed and focused by union officials and local representatives (Cunningham, 2008; Darlington, 2009; Gajewska and Niesyto, 2009; Wood, 2015; Manky, 2018). Their role is vital to ensure that blame is attributed explicitly to the employer, and to galvanise aggrieved workers into opposition from a shared conviction that collective action can change their situation.

As others have acknowledged (Cox et. al., 2007; Cunningham, 2008; Murphy and Turner, 2014, Darlington 2018), Kelly's mobilisation theory promotes an integrated appreciation of structural factors (including market, institutional and regulatory pressures) and their effect on the struggles between employers and union activists. It also provides a basis for applied research on the practicalities of union organising and campaigning. Subsequent applications of mobilisation theory have focused heavily on the respective strengths and limitations of 
union activism in particular settings. These studies aim to draw lessons about viable ways of developing union capacity, strategies and processes to increase overall union effectiveness (Gall, 2003; Kelly and Badigannavar, 2004; Simms, 2007; Gajewska and Niesyto, 2009; Wood, 2015).

Despite some critical reaction to the treatment of leadership in the original framework (Fairbrother, 2005) and to the relative neglect of grassroots activism (Atzeni, 2009; Holgate et alia., 2018), functional accounts of union enabling and capacity building predominate. The problems of mobilising that command attention tend to be those of union officials and activists. These include threats to social identification and group cohesion that emerge from the counter-mobilising activities of employers, and the role of officials' and activists' in swaying reticent or fickle workers (Kelly and Badigannavar, 2004; Cox et. alia, 2007; Cunningham, 2008). There is no real sense that perceptions of grievance and injustice at work reach beyond employers to unions themselves, their activists, strategies or negotiated agreements. Nor is there much discussion of contradictory behaviour or union countermobilizing alongside employers - to the detriment of employee interests - even in accounts of ineffectual organizing. Such questions are, however, particularly pertinent when examining cases of pay equality. Extant writing suggests that unions, for example through a lack of familiarity, might fail to represent female dominated occupations at the bargaining table adequately (Gilbert et al., 2012). Indeed, the contribution that unions have made to pay equality is often evaluated more successfully in the academic literature than by working women themselves (Poling, 2005; Beirne and Wilson, 2016).

These issues in equality bargaining suggest an element of myopia in neglecting forms of representation beyond the formal union hierarchy. The mobilisation literature following Kelly is relatively light on the significance of grassroots and non-union, third party interventions to address injustice or demonstrable inequalities across different sectors (Parsons and Priola, 2013). This is a key emerging issue around gendered pay inequality, certainly at the micropolitical level. Women are reacting to persistent pay inequalities in more direct and innovative ways (Beirne and Wilson, 2016). They are more confident in expressing disenchantment with traditional forms of representation, including union equality bargaining. A mobilisation theory that fails to account for critical grassroots reaction to prevailing patterns of trade unionism appears inadequate, especially if it deflects attention from the impact of competing third party contributions. Given that traditional conceptions of union mobilisation may not extend to equal pay disputes, the question arises as to whether the theory is fundamentally about union growth and effective union representation, or tackling injustice and disadvantage.

This article therefore argues that the time is ripe for a re-appraisal of John Kelly's mobilisation theory. Reflecting upon the politics of equality activism in the British local authority sector through a secondary case discussion, it highlights some important limitations. Specifically, weaknesses are found with how the theory treats the attribution of responsibility for injustice by workers, and the attention given to union leaders as agents of positive change. The front line agency of disadvantaged women, and the material conditions that encouraged many low paid council workers to take a stand against their unions, as well as their employer, indicates that these key categories need to be reconceptualised. The propensity of these working women to align with alternative representatives in a complex interplay of adversarial and cooperative relations - between unions, an employer (Glasgow City Council) and 
litigation specialists (Action-4-Equality Scotland) - demonstrates the importance of embracing ideas about distributed leadership (Gronn, 2008; Beirne, 2017). The analysis gives specific attention to coalition building, and also to shifting and fluid patterns of allegiance, within a revised mobilisation theory.

\section{Leadership and Attribution as Problematic Categories}

There is a strong tradition of equality activism within the union movement, and a record of achievement by leaders at different levels securing valuable gains through negotiated agreements and the pursuit of landmark legal rulings (Dickens, 2000; Beirne and Wilson, 2016). Their interventions are deeply appreciated by women who have experienced discrimination. However, there is often the qualification that unions and leaders were pushed into this sort of mobilisation by frontline female workers who were frustrated by an initial reluctance and lack of interest to act on equality issues (Beirne and Wilson, 2016). Conservative leadership inclinations and the defence of male interests and pay differentials have cast doubt on the capacity of trade unions to act consistently and effectively on gender equality (ibid).

This is not a controversial line of argument. It is widely accepted that British unions have struggled with equality, regularly prioritising the interests of male members at the expense of women (Dickens, 2000; Conley, 2013). Although expressing more obvious concerns about discrimination over the last decade and more, union leaders have been reluctant or worried activists for gender equality. Some seem just as likely as many employers to spin rhetoric and present an appearance of useful intervention on equality issues, which may not reflect reality (Hoque and Noon, 2004; Beirne and Wilson, 2016).

There is now a substantial literature on women's attitudes towards unions, and this points to a deep disillusionment, especially in the public sector. Recent work follows earlier studies by Tomlinson (2005) and Walters (2002) in highlighting negative attitudes and experiences, often based on the sense that unions were of little or no help when women raised grievances about their employment (Beirne and Wilson, 2016). While some union leaders are undoubtedly keen to address historical criticism about inadequate representation, there is a lingering suspicion that union interests are frequently at odds with those of working women. This may be unintended rather than calculated, or because unions lack the requisite expertise to bargain effectively over terms and conditions in occupations dominated by women (Gilbert et al., 2012). Nevertheless, there has been a failure of union leadership, meaning that many working women do not have an adequate collective voice to secure pay equality (ibid). It may be the case that injustice is partially attributable to unions, whatever their motives, either separately or alongside employers. The corollary is that extant thinking about attempts to hold employers accountable is partial, and that the processes involved in attributing blame for injustice are more complicated than Kelly's theory indicates. These considerations also cast doubt on the functional notion of leadership that informs much of the literature on mobilisation theory. The tendency to apply rather than reconceptualise Kelly's framework is deeply ingrained, however, and a matter for ongoing scrutiny (notably in the recent special edition edited by Gall and Holgate, 2018).

Cox et al. (2007) provide a notable example, since they deal directly with the mobilisation of gendered grievances. Following an acknowledgement of the difficulties for unions on this 
front, they reinforce Kelly's ideas about the dependence of workers on union activists. With empirical data indicating that employee grievances failed to escalate or generate sufficient momentum for collective action, Cox et al.'s study concentrates on barriers to effective mobilisation. However, much of the commentary contrasts the hesitancy of women and their propensity to contain legitimate grievances with the empowering potential of enlightened union organising. Union activists emerge as enabling rather than inhibiting agents, with little obvious doubt about their potential role as the architects of successful mobilisation:

Representation mechanisms and the presence of activists to engage with women at workplace level act as a prerequisite to encourage them to voice their concerns. [Cox et. al., 2007: 735]

This is a familiar theme in applications of mobilisation theory. Many studies (Johnson and Jarley, 2004; Cunningham, 2008; Darlington, 2009; Murphy and Turner, 2014; Wood 2015) call attention to the actual or potential leadership contribution of union activists, inviting comparison with orthodox and 'heroic' notions of 'leaderism' in the business and management literature (O'Reilly and Reed, 2010). There are unpalatable similarities in the treatment of followers. The suggestion is that members need to be directed by favoured and enlightened others who have the particular knowledge and insights required to create an alternative vision that transforms them into a cohesive organisational force (Johnson and Jarley, 2004:557). There is a tendency with mobilization theory to mirror the business consultancy concern for understanding and developing the contributions of these pivotal or privileged agents. In turn, this casts workers as broadly passive and dependent, requiring their awareness of grievances to be stimulated and intensified before they engage in appropriate forms of organised behaviour.

The conventional business treatment of leadership has been effectively critiqued for overstating the capabilities, and exaggerating the functional significance of those in formal positions of authority and influence (Beirne, 2017). Independent investigations into scandalous leadership failures in banking and health care have cast doubt on traditional assumptions about the rise to prominence of able and suitable groups of actors who can be trusted to deliver enlightened guidance and safe governance (e.g. The 'Francis Report', 2013). Empirical studies have also pointed to the importance of distributed rather than directed change agency. These have prompted fundamental debates about the nature of leadership, whether it relates to shared qualities and collective responsibilities, or can be reduced to matters of position, charismatic authority and professional expertise (Buchanan et. al., 2007; Gronn, 2008).

This is not to suggest that leaders, be they business executives or union officials, are insignificant agents, or that their respective roles in shaping collective behaviour are essentially the same or similarly flawed. The point is rather to highlight the relational interdependence between leaders, followers and other agents (such as regulators, investors or journalists), and the danger of deflecting attention from the working out of complex and often tension-laden interactions. Some doubts have already been expressed about this as a weakness in Kelly's framework. Fairbrother (2005) took issue with 'vanguardist' thinking, attracting a dismissive reaction from Darlington (2009) who confidently reinforced the established linkage between workplace activists and successful mobilisations (though later acknowledged some of the points arising from this critique, Darlington, 2018). Significantly, 
from case research in the Argentinian car industry, Atzeni (2009) called attention to the informal localised leadership of frontline workers. In this context of politicised trade unionism, where doubts were expressed about the allegiance of officials, worker militancy escalated because of grass roots activism. For Atzeni, it was 'spontaneous', 'non-organized' and therefore beyond the compass of mobilization theory, inverting the linkage between formal leaders and collective action (2009:6). Whilst Darlington (2018: 627) maintains that Kelly did not assume that action was only 'predicated on pre-existing formal (union) leadership', the fact remains that this is strongly implied in Kelly's (1998) writing (e.g. with the focus on shop stewards).

While gender was not a part of Atzeni's analysis, perceptions of injustice on this front seem just as likely to produce examples of self-organisation and similar forms of grass roots mobilisation. There has been some discussion of this in relation to union representation, although the focus has been on women combining, organising and politicking within unions to secure greater influence and access to leadership positions (Cox et. al., 2007; Simms, 2007). This undoubtedly helps to counteract images of passivity and dependence, drawing attention to active agency and the thoughtful, resourceful behaviour of people who are capable of identifying and addressing the obstacles they face. However, popular thinking around mobilisation theory still insists that the grass roots must be orchestrated (Wood, 2015), and that front-line agency must be manipulated by 'issue entrepreneurs' (Manky, 2018: 582). Spontaneous action fizzles out and, from this perspective, if mobilisations are to be more than short run expressions of resistance, purposeful union leadership is required. Simms (2007) notes that legitimate grievances are not always raised spontaneously by workers. Drawing lessons from the not-for-profit sector and mobilisations driven by union professionals and not workers, she suggests that transformational leadership is important. This is in tune with the broad thrust of leadership thinking in mobilisation theory, although there remain echoes of the business usage of this phrase. The behaviour of followers is transformed by leaders acting on them rather than with them, to the extent that their independent critical agency fades out of focus.

This treatment is evident in union debates about managed activism and the working out of leadership roles at national, regional, sectoral and branch levels (Simms, 2007; Gajewska and Niesyto, 2009; Murphy and Turner, 2014; Darlington, 2018). While tensions are recognized along with the effects of contradictory behaviour in stalling or dissipating mobilisations (Cunningham, 2008; Taylor and Bain, 2003), the agency that commands attention is quite tightly contained within union hierarchies. The problems, reactions, interventions and struggles that inform the analysis are predominantly those of union professionals and representatives. The applications of this work reproduce a functional approach to leading mobilisations, ensuring that workers attribute blame appropriately and become receptive to being mobilised. Managed activism suggests that success is contingent upon local representatives concentrating their leadership on orchestrating worker opinion, identifying 'winnable' issues, providing a first response to employer counter-mobilising and building solidarity. Union professionals play their part by supporting local expertise with access to resources and strategic direction to ensure consistency with wider policies, agreements and priorities. This is presented as both top-down and bottom-up in a way that resonates, somewhat, with distributed leadership thinking. Yet restrictions on this are also discernible, with the relative neglect of leadership roles among front line workers, and the absence of 
analytical space for mobilising leadership contributions from beyond the unions. In this vein, Darlington (2018: 632) recently acknowledged the need for further development of mobilisation theory to account for external 'sources of influence and pressure'.

Again, there is no doubt that union leaders have an important influence on mobilisations against injustice and for equality. However, the attention given to the framing and orchestration of collective action within the mobilisation literature is restrictive. The concern here is that agency is conceptualised narrowly and with a prescriptive focus on union influence and capacity building that makes it difficult to account for the full range and complexity of mobilising activity. Kelly's categories that deal with the attribution of blame for injustice and reliance on trade unionists have deflected attention from the mobilising activities of workers themselves, the emergence of their own grass roots leadership abilities and the impact of other third-party forms of representation.

The literature on gender inequality suggests that the experience of dealing with union leaders can indeed heighten workers' feelings of injustice, though not always in the anticipated direction. Instead of encouraging them to 'be union' (Markowitz, 2000), it may push them towards more of an oppositional stance. Workers may need to have a perpetrator in mind before they engage meaningfully in collective action (Johnson and Jarley, 2004), although their own interpretation of events could 'lead' them to challenge rather than internalise union arguments. The research mentioned earlier on women's attitudes towards unions, and their reactions when they perceive that male interests dominate union negotiating, demonstrate that this is more than idle speculation. It adds weight to Atzeni's (2009) argument that greater attention should be given to worker militancy, and how this can challenge both unions and employers. From the standpoint of some women seeking pay equality, unions are not so reliably on the side of justice, or able to deliver meaningful progress towards pay parity. Taking worker agency as a more active category, and one that raises additional patterns of allegiance and representation for mobilisation theory to accommodate, this paper presents distributed leadership as an alternative to functional, union-dominated thinking.

\section{Contested and Compromised Mobilisation: Activism on Local Authority Pay}

To interrogate these themes, we develop a secondary case analysis of an organisation in the British local authority sector, Glasgow City Council (GCC). This is a highly controversial and widely covered case where activism remains necessary to correct for gendered pay inequality. Developments in this context provide a promising terrain for some reinterpretation of the coverage and utility of mobilisation theory. The case reveals tensions in equality bargaining and challenges to both employer and unions 'from below' (Ramsay, 1977) and beyond traditional representative structures (Beirne and Wilson, 2016).

Much has already been written about local authority problems with equal pay (Perkins and White, 2010; Deakin et. al., 2015) and the GCC case is well known, with large amounts of information available for public scrutiny. The founders of litigation specialists, Action 4 Equality Scotland (A4ES) - Mark Irvine (a senior ex-UNISON official) and Stefan Cross (an employment lawyer, ex-union activist and Labour councillor with a track record of representing council workers in England) - had a major impact on this case, signing large numbers of GCC women to 'no-win-no-fee' legal representation. Exchanges between the 
main protagonists - UNISON and GMB officials; successive GCC council leaders and councillors; Irvine and Cross; and prominent women working for GCC - have been played out in public, through social media and other online activities (e.g. blog posts, open letters and chatrooms). Information in this vein was gathered from the A4ES website, Mark Irvine's blog, twitter and public forums on UNISON Glasgow City Branch's Facebook pages. Whilst many posts are partial in and of themselves, they provide essential reference points for analysing the interventions and representation of key actors, and also for gauging the reactions of union members and front line workers. Media reporting and journalism (referenced below) was also important in this case, providing the outlet for a 'war of words' between union officials, councillors and Irvine and Cross. Investigative journalism aired on national television (Poling, 2005; Corbin, 2018; Robinson, 2018) was particularly useful in calling attention to the views and experiences of the working women. This material was cross-referenced against other publicly available documents, including GCC council minutes, Scottish Parliament committee minutes, legal case documentation and reports from Audit Scotland (Scotland's public auditor).

\subsection{Re-mobilising the disaffected}

Through the 1990s, British councils were vulnerable to equal pay cases arising from historical agreements with unions that inflated male pay with bonus schemes that were not available to women (Deakin et al., 2015). Equal pay claims were growing and proving expensive, prompting councils and unions to seek new agreements that would unify the pay structures of different groups of workers through job evaluation exercises. These 'Single Status Agreements' would harmonize terms and conditions to ensure parity for men and women on the same grade, regardless of traditional gendered job segregation (Perkins and White, 2010). Scottish councils and trades unions pursued their own version of single status from 1999, although with considerable variation as particular councils took account of local circumstances. Whilst there was a single pay spine, it was delegated to local authorities to locate jobs within this spine, effectively making single status a misnomer (Gilbert et al, 2012). Glasgow City Council developed its own scheme, the Workforce Pay and Benefit Review (WPBR), implementing this from 2006 (GCC, 2018). The principle of equal pay for work of equal value was not well served by this, however.

Affordability was a concern here, as elsewhere (Gilbert et al., 2012; Deakin et. al., 2015). Councillors feared serious financial consequences and industrial unrest leading to approaches that 'did not always prioritise pay equality' (Audit Scotland, 2017: 3). Irvine's blog (2017) notes that the GCC unions originally threatened to strike to protect the pay of male dominated jobs, though not to protect women members. Caught between budget constraints and the risk of industrial unrest, pay protection arrangements were negotiated at GCC to soften the impact on men who were likely to see a reduction in their earnings (People Management, 2017). Whilst common within the sector (Deakin et al., 2015), in Glasgow, this prompted a dramatic increase in equal pay claims on two fronts, against the discriminatory impact of historical schemes and against the WPBR itself.

Action against employer and union positions was escalated by the GCC women themselves, through the circulation of tweets and emails about A4ES, with some organising meetings in church halls and community venues across the city where Irvine was invited to speak and explain the service on offer (Poling, 2005). Enacting A4ES' (2018) principle that 'shy bairns 
get nowt', claimants ensured that the equality problems posed for GCC were far greater than those facing any other Scottish council. According to Audit Scotland (2017) figures, GCC received 22,730 equal pay claims during the 11 years to September 2016, more than double the number for the next council on the list (North Lanarkshire at 10,480, which was still far higher than any of the others, also as a result of A4ES activity (Ridley, 2015)). Compensation payments during this period cost GCC $£ 53.8$ million, again more than double the amount paid by other Scottish councils. Over $40 \%$ of all the live claims in Scotland at the end of September 2016 were lodged against GCC $(11,065)$. Whilst this is the largest local authority in Scotland (Campbell and Burrowes, 2016), its share of claims remains highly disproportionate.

\subsection{Blending adversarialism with measured cooperation: surprising alliances?}

There were two distinct phases to the working out of relations between the unions and A4ES in Glasgow, from 2005 through the implementation of WPBR to the early-mid 2010s and thereafter with challenges to this scheme. As A4ES started to recruit Glasgow claimants in August 2005, the unions were reaching a compensation agreement with GCC that would deliver a one-off payment of up to $£ 9000$ to each disadvantaged worker (The Herald, 2005). This was announced in the autumn, with journalists reporting it as a Christmas bonus, much to the annoyance of women who felt that attention was being deflected from discriminatory treatment over many years (Poling, 2005).

Cross and Irvine were highly active during this period. The latter in particular highlighted perceived union complicity in magnifying disadvantage through multiple blog posts, media comment and evidence given to the Scottish Parliament (2009). This provoked strong reactions from union officials and councillors. Together they attacked the opportunist 'ambulance chasing' and hawkishness of A4ES (The Journal, 2005; UNISON, 2009), echoing wider criticism of Cross (Cooper, 2006; Hattenstone, 2010). The exchanges were acrimonious, as Cross was seen as an enemy of the union movement having won a case against the GMB in England - the Allen litigation - for failing to represent their female members adequately (Deakin et. al., 2015). Many GCC women were fiercely critical of the union position, however, siding with A4ES to produce a dramatic increase in the tribunal caseload pursued by Cross (Poling, 2005; The Herald, 2007).

By the 2010s, it was clear that A4ES litigation was securing valuable settlement packages for GCC women, and that pressures arising from this were encouraging at least some union officials to modify their approach. There were signs of a change in the Unions' mood and elements of cooperation in working against the employers throughout Scotland. This was reportedly more evident within UNISON than GMB (Ridley, 2015). Frustration at union (in)action from 2005 on Irvine's blog (supported by published comments from trade union members) is directed mostly towards the GMB (e.g. Irvine, 2017b). However, critiques of UNISON's past actions are also evident, indicating potentially tense alliances (e.g. Irvine 2017c).

Despite these tensions, the unions and A4ES began jointly challenging GCC in the courts, including successfully dismissing claims from the employer that women working in 'arm'slength' outsourcing organisations should be excluded from equal pay claims ${ }^{1}$. However, the

\footnotetext{
${ }^{1}$ Fox Cross Claimants and others v Glasgow City Council and others (2013) UKEATS/0027/12/BI
} 
GMB's lawyers adopted a narrower approach than A4ES and UNISON, and did not directly target the discriminating nature of the WPBR scheme itself (see Irvine 2017a; McDonald and Others vs. Glasgow City Council, 2014²). Subsequent protracted litigation reflecting the combined contributions of A4ES and UNISON (not GMB) successfully targeted the WPBR scheme, with the Court of Session (Scotland's highest civil court) ruling in August 2017 that the scheme was not demonstrably compliant with the equal pay legislation ${ }^{3}$. In December 2017, the Court of Session denied GCC leave to appeal (BBC, 2017a and b). At a meeting of the City Administration Committee in January 2018, councillors decided not to challenge this in the UK Supreme Court, committing themselves instead to settling outstanding claims and working with the unions and A4ES to devise alternative, legally compliant, arrangements (Audit Scotland, 2018). A Job Evaluation Work Stream was established, with council officials advising the next meeting of this committee (in June) that UNISON and the GMB were actively involved, utilising technical assistance from A4ES (GCC, 2018). However, there was no sign of a replacement for the WPBR at the time of writing.

\section{Solidarity Beyond and Against the Unions}

The sense of injustice among the GCC women was, and remains, palpable. For most of the last decade, it was directed jointly towards their unions and employer as they turned in large numbers to A4ES, apparently deciding that their grievances could be more fully resolved through no-win-no-fee lawyers. Could this be identified or effectively analysed via the established categories of mobilisation theory? In this instance, the limitations of the framework are more obvious than the strengths. The case demonstrates the conceptual limits of a mobilisation theory that relies on functional notions of union leadership to the neglect of independent grass roots activism and alternative channels of representation.

Applications of Kelly's (1998) mobilisation theory indicate that successful action to redress inequality is contingent upon union organisation and leadership. There are strong suggestions that workers fail to appreciate the extent of their disadvantage, and are likely to be taken in by the 'inhibiting attributions' of employers that deflect blame for pay grievances to factors beyond their control. Women are often considered to be more reluctant to protest than men, less willing to articulate concerns about unfair treatment, and thus to seem particularly reliant on union guidance (Cox et. al., 2007).

This was not the case at GCC. The presence of union activists was negative in the perceptions of many women workers, and modest in outcomes by comparison with the scale and coverage of legal challenges from Cross and A4ES (Poling, 2005; The Herald, 2007; BBC, 2017a; Robinson 2018). Worker collectivism was galvanised against both the unions and the employer, with reinforcing interventions emerging from within worker communities (especially the home carers) and A4ES.

Inhibiting attributions were coming from union officials who were worried about jobs and (according to Irvine, 2017) reactions to shrinking male differentials. Union officers originally 'sold' the compensation package of 2005 as the best that could be achieved in the prevailing financial climate (The Herald, 2005). In Tomlinson's (2005) study of women's attitudes

\footnotetext{
2 J MacDonald and Others vs. Glasgow City Council (2014), UKEATS/0008/14/BI

3 J Armstrong and Others and J. McDonald and Others vs. Glasgow City council (2017), CSIH56/XA71(2)/16
} 
towards unions, some respondents felt capable of negotiating their own interests, considering unions unnecessary. At GCC, the grassroots feeling, as demonstrated by communications shared on Irvine's blog and subsequent legal actions, was that women could not rely on the unions to tackle injustice. Some took the view that they were 'hand in glove' with Labour councillors (and hence the employer) and unwilling to 'rock the boat' during negotiations about compensation and the WPBR (Poling, 2005). Women's perceptions of injustice were sharpened by union pragmatism and critical collective reaction to their politicking. Even before A4ES started exerting a mobilising influence, there were signs that prominent women, especially among the home care workers, understood the nature of their disadvantage and were pointing fingers at the unions (Poling, 2005).

Mark Irvine called attention to the extent of the pay inequalities at GCC, although it seems wrong to follow the early reaction of some union officials that the women were vulnerable to the spin of opportunists. Unlike the workers studied by Cox et. al. (2007), there was no generalised tendency to assume that pay agreements were fair or that faith could reasonably be placed in union negotiating positions, hence the number pursuing claims through nonunion routes. Women themselves were circulating information to draw attention to A4ES among their colleagues across the city, and arranging meetings for Irvine to speak (Poling, 2005). Notable grass roots enthusiasts for A4ES emerged, such as Frances Stojilkovic. This was picked up in television journalism that followed her at work, to hear what she had to say and how she applied some influence to mobilise others (Robinson, 2018). This local agency made a difference in speaking to the wider disaffection with the unions, and stimulated interest in finding alternative ways forward.

Of course, the interventions of A4ES are also vitally important for understanding how so many women came to align themselves against the unions and GCC. Irvine and Cross covered gaps in the representation of these disadvantaged women and changed the means whereby their grievances could be resolved. A4ES forced the issue with the unions and the employer through the courts, magnifying discriminatory agreements and demonstrating to the women that they could collectively find another form of redress. Mobilisation theory underlines the importance of union credibility, in workers coming to believe that their representatives can tackle injustice. This also applies to the mobilising capacity of A4ES. Cross secured positive outcomes for claimants reasonably quickly, heightening the sense that signing to A4ES was less of a risk or a rip-off than union leaders initially claimed.

Studies of union organising have often pointed to the danger of officials and representatives being sidelined by employer counter-mobilising (Cunningham, 2008; Cox et. alia, 2007). In the Glasgow case, A4ES was having the same sort of impact. Beyond the success in the courts, and in response to the early hostility of union activists and councillors, Irvine was actively constructing a narrative on the discriminatory and contradictory nature of local unionism, for example through his many blog posts and evidence given to the Scottish Parliament (2009). He was purposefully counter-mobilising in ways that have been associated with good trade union leadership. Wood (2015) highlights the effectiveness of a shaming strategy to damage the reputation of Walmart, while Simms (2007) shows how the commitment that charitable organisations attach to fair treatment and caring for others can be turned against them as a means of pushing for improvements in their staffs' terms and conditions. Irvine applied this to the unions themselves (as well as the employer), putting 
them in the dock of worker opinion for adding to their difficulties and perpetuating disadvantage, contra to their rhetoric about being seriously committed to equality.

Social media and online communication was indispensable, enabling the sort of 'swarming' activity that Wood recognises, with negative tweets, blogs and internet posts reaching a large audience and prompting further negative comment. By the more cooperative stage in relations between the unions and A4ES, this 'swarming' was more obviously targeting the employer. Irvine was leading much of the activism on this front, for instance, with freedom of information requests, tweets and posts on his A4ES blogsite. He also highlighted the hypocrisy of councillors using public funds to cover excessive 'golden goodbyes' to senior officials (Irvine, 2017c) whilst fighting the equal pay claims and failing to improve the pay of frontline women workers. His blog also provided the email addresses of all Glasgow members of the Scottish and Westminster parliaments, encouraging readers to raise issues and request support for pay equality at GCC (Irvine, 2017d). Informal leadership interventions from women such as Frances Stojilkovic raised the volume of critical communications (Robinson, 2018), and ensured that activism through social media complemented more traditional campaigning.

Council leadership moved from Labour to the SNP (Scottish National Party) in 2017, with GCC court appeals ongoing. This change provided an opportunity for some skilful politicking by Irvine (e.g. 2017e) to encourage the new administration to settle the dispute. Recognising that GCC officials were still inclined to challenge the Court of Session ruling on the WPBR scheme, this effort sought to magnify the reputational risks for SNP councillors if a UK authority was asked to overrule a Scottish court. By 2018, A4ES and UNISON were mobilising workers together for demonstrations at the Council Chambers. The Council Leader, Susan Aitken, expressed her own view, publicly, that it was time to end the legal process and find a joint solution with the unions and A4ES (Paterson and Stewart, 2018). However, frustration at the lack of progress prompted further complementary mobilising, with leadership influence exerted between the unions and A4ES in the Job Evaluation Work Stream. The Glasgow City Branch of UNISON Facebook page bow reported that A4ES and both unions were presenting a 'united' front at these meetings.

At the time of writing, this frustration had boiled over. A two-day strike, involving both unions occurred in October. GCC leader, Susan Aitken, has attacked the unions in the press for the strike and their previous inaction on equal pay, accusing them of misleading the women (Evening Times, 2018). Exchanges are ongoing between the main protagonists on Twitter. Leadership influences remain distributed through the mobilisation rather than concentrated at a specific level. Whilst it could be argued that Irvine and Cross maintained more 'traditional' leadership positions through knowledge, status and power, their positions relied heavily on the distributed influence of the grassroots activists who were themselves key leaders. Essentially this form of distributed leadership extended beyond the positional and representative capacities of union leaders, and beyond the unions themselves.

\section{Conclusion}

Who or what is mobilisation theory for? Is it fundamentally about union growth and effective union representation or tackling injustice and disadvantage? Kelly's original 
formulation was geared to rejuvenating industrial relations as a discipline and route to fair practice, against those prepared to write it off in a hasty fashion. It also prioritised union development and effective functioning, via the leadership of union officials and activists. Unfortunately, this part of the analysis tends towards an unduly simplistic notion of leadership within unions, privileging formal union leadership contributions and tending to deflect attention from grass roots and alternative channels of influence. Forms of third party representation, which might better represent members' interests, are discounted. Overall, this leads to an unduly positive endorsement of the role of unions, which can be questioned, certainly in terms of gender equality. If mobilisation theory is to provide a comprehensive analytical framework for understanding collective action (or inaction), alternative possibilities for representation and leadership need to be accommodated. Mobilisation research cannot be confined to, or equated solely with, union organising or capacity building. Without broader attention to the questions we posed earlier, it appears that mobilisation theory will deliver only a partial account of collective action that aims to challenge injustice and secure fair treatment.

Empirically, the GCC case demonstrates that unions can be blamed (at least in part) for injustice along with employers, seeming culpable to some members for agreements that perpetuate disadvantage, despite their public pronouncements. Their manoeuvring and spinning of media interest were taken here as signs of complicity, sectionalism and incompetence, which other representative interests and agencies seemed able to address and harness to great effect. A4ES mobilised the wider community of GCC women against both the employer and the unions (Poling, 2005).

The GCC case also reveals how the role of union officials and activists was of concern to workers, providing additional reasons to be cautious about conceptual slippage to assumptions about positive, constructive and uncompromised union leadership. In fact, leadership influences were distributed through the mobilisation (Robinson, 2018). They were not restricted to union officials. A4ES was counter-mobilising with a well-developed critique of union positions, casting doubt on their credentials as reliable equality activists. Many of the GCC women had already reached this view, although the informal leadership that emerged at this level, especially among the home care workers, was important during the early stages of building momentum behind the A4ES litigation. Prominent workers developed a view of the constraints and possibilities, and they intervened to move others, meeting and communicating to articulate the case for submitting equal pay claims on an unprecedented scale. These workers were not simply steered from above. The leadership agency in this case was complex and multi-layered, involving shifting alliances and combinations of adversarialism and coalition building that underline the need for more nuanced ways of capturing the dynamics of mobilisation.

Theoretically, these insights highlight the need for an extended mobilisation theory which considers the complexities revealed by the GCC case. The tensions and patterns of allegiance at GCC demonstrate the importance of accounting for shifting positions, including the possibility of 'unholy alliances' developing between unions and employers - and also party political interests - and to consider the impact of any critical worker reaction to these on grass roots mobilisation. The matter of alternative strategies and forms of representation to those pursued by union officials and activists merits serious attention in mobilisation theory, with more explicit scrutiny of moderating and counter-mobilising tendencies, both inside and 
outside the unions. Kelly (1998) has already extended Tilly's (1977) mobilisation theory through his focus on the social dynamics of the mobilisation process. The analysis in this article suggests that the process requires further unpacking and elucidation to account for the complexity of unfolding relationships between union officials, activists, workers and third parties, with a more obvious sense that mobilisation may occur contra to the framing of union leaders.

The wider significance of mobilising agency was raised as a concern in reviews of Kelly's initial outline (e.g. Fairbrother, 2005). Some of the critical reaction aimed to draw lessons from spontaneous grassroots activism, inverting the top-down emphasis and demonstrating that union leadership is not a precondition for success (see for example Atzeni, 2009). The GCC case extends this, directing attention to the connections between grass roots activism and extra-union agency, and demonstrating that these can dovetail to reshape successful mobilisation processes. Recently, Darlington (2018) called for a greater focus on the role of external agents and how they might facilitate union interests. One of the lessons from the GCC experience is that these may mobilise contra to union leadership, leading to a complex interplay of shifting allegiances and leadership processes. The corollary is that greater theoretical attention should be given to distributed leadership (Gronn, 2008; Beirne, 2017), with a shift away from 'heroic' or 'transformational' explanations. Although largely defending his position, even Kelly (2018: 705) in his afterword to the recent special edition acknowledges that his 1998 work 'devoted little attention to (how) ... workplace activists become leaders with followers' (emphasis added). This analysis of GCC indicates that something more complex and widely encompassing is required. It is insufficient to consider emergent leader/follower relationships within union structures. Further research is needed to consider the various stages of protracted disputes, and consider how mobilising relationships between workers, union and extra-union agents develop and change over longer periods. Given the more symbiotic relationships that developed during the autumn of 2018 between the various unions in the GCC case and A4ES to jointly oppose the employer, the notion of dynamic temporal relationships could add yet another layer to a revised mobilisation theory.

\section{References}

Action for Equality Scotland (A4ES) (2018) Frequently Asked Questions, available at https://www.a4es.co.uk/faqs/

Audit Scotland (2017), Equal Pay in Scottish Councils (Edinburgh: Audit Scotland), available at http://www.auditscotland.gov.uk/uploads/docs/report/2017/nr_170907_equal_pay.pdf

Audit Scotland (2018) Best Value Assurance Report: Glasgow City Council 9Edinburgh, Audit Scotland), available at http://www.auditscotland.gov.uk/uploads/docs/report/2018/bv_180823_glasgow.rtf

Atzeni, M. (2009), 'Searching for Injustice and Finding Solidarity? A Contribution to the Mobilisation Theory Debate', Industrial Relations Journal, 40, 1, 5-16. 
BBC (2017a), 'Campaigners Hail Glasgow City Council Equal Pay Ruling', BBC News, 18 August. Available at: http://www.bbc.co.uk/news/uk-scotland-glasgow-west-40975929 (accessed 2 May 2018).

BBC (2017b), 'Council Appeal Refused in Women's Equal Pay Dispute', BBC News, 22 December. Available at: http://www.bbc.co.uk/news/uk-scotland-glasgow-west-42446135 (accessed 2 May 2018).

Beirne, M. (2017), 'The Reforming Appeal of Distributed Leadership', British Journal of Healthcare Management, 23, 6, 262-270.

Beirne, M. and F. Wilson (2016), 'Running with "Wolves" or Waiting for a Happy Release? Evaluating Routes to Gender Equality', Work, Employment and Society, 30, 2, 220-236.

Buchanan, D., R. Addicott, L. Fitzgerald, E. Ferlie and J. Baeza (2007), 'Nobody in Charge: Distributed Change Agency in healthcare', Human Relations, 60, 7, 1065-1090.

Campbell, A. and E. Burrowes (2016), 'Financial Scrutiny Unit Briefing Subject profile local government in Scotland', Scottish Parliament Information Centre Briefing (Edinburgh, Scottish Parliament). Available at http://www.parliament.scot/ResearchBriefingsAndFactsheets/S5/SB_1669_Subject_profile_local_government_in_Scotland.pdf

Conley, H. (2013), 'Trade Unions, Equal Pay and the Law in the UK', Economic and Industrial Democracy, 35, 2, 309-323.

Cooper, N. (2006), 'No-Win-No-Fee Lawyers are a Threat to the Success of Local Government Equal Pay Negotiations', Personnel Today, 5 December.

Corbin, J. (2018), 'Britain's Equal Pay Scandal', BBC Panorama, 19 March.

Cox, A., S. Sung, G. Hebson and G. Oliver (2007), 'Applying Union Mobilization Theory to Explain Gendered Collective Grievances: Two UK Case Studies', Journal of Industrial Relations, 49, 5, 717-739.

Cunningham, I. (2008), 'Mobilising Workers within Inter-organisational Relationships in the UK Voluntary Sector', Industrial Relations Journal, 39, 3, 191-211.

Darlington, R. (2009), 'Leadership and Union Militancy: The Case of the RMT', Capital and Class, 33, 3, 3-32.

Darlington, R. (2018) 'The leadership component of Kelly's mobilisation theory: Contribution, tensions, limitations and further development', Economic and Industrial Democracy, 39, 4, 617-638.

Deakin, S., S. Fraser-Butlin, C. McLaughlin and A. Polanska (2015), 'Are Litigation and Collective Bargaining Complements or Substitutes for Achieving Gender Equality? A Study of the British Equal Pay Act', Cambridge Journal of Economics, 39, 381-403.

Dickens, L. (2000), 'Collective Bargaining and the Promotion of Gender Equality at Work', Transfer: European Review of Labour and Research, 6, 193-208. 
Evening Times (2018) 'City council leader speaks out on equal pay strike', Evening Times, $11^{\text {th }}$ October. Available at. https://www.eveningtimes.co.uk/news/16974558.city-councilleader-speaks-out-on-equal-pay-strike/

Fairbrother, P. (2005), 'Book Review of G. Gall (ed) Union Organizing: Campaigning for Trade Union Recognition', Capital and Class, 37, 257-263.

Francis, R. (2013), 'Report of the Mid Staffordshire NHS Foundation Trust Public Inquiry' (London, HMSO).

Gajewska, K. and J. Niesyto (2009), 'Organising Campaigns as "Revitaliser" for Trade Unions? The Example of the Lidl Campaign', Industrial Relations Journal, 40, 2, 156-171.

Gall, G. (ed) (2003), Union Organizing: Campaigning for Trade Union Recognition (London, Routledge).

Gall, G. and J. Holgate (2018) 'Rethinking Industrial Relations: Appraisal, application and augmentation', Economic and Industrial Democracy, 39, 4, 561-576.

Gilbert, K., C. Warhurst, D. Nickson, S. A. Hurrell and J. Commander. (2012), 'New initiative, old problem: Classroom assistants and the under-valuation of women's work', Industrial Relations Journal, 43(1): 22-37.

GCC (2018) Future of Current Pay and Grading System, City Administration Committee Item $428^{\text {th }}$ June 2018, available at

http://glasgow.gov.uk/councillorsandcommittees/viewSelectedDocument.asp?c=P62AFQDN 2UZLZ3DXNT

Gronn, P. (2008), 'The Future of Distributed Leadership', Journal of educational Administration, 46, 2, 141-158.

Hattenstone, S. (2010), 'The Most Hated Lawyer in Britain', The Guardian, 1 May.

Holgate, J., M. Simms and M. Tapia (2018) 'The Limitations of the Theory and Practice of Mobilization in Trade Union Organizing', Economic and Industrial Democracy, 39, 4, 599616.

Hoque, K. and M. Noon (2004), 'Equal Opportunities Policy and Practice in Britain', Work, Employment and Society, 18, 3, 481-506.

Irvine, M. (2017) Glasgow and Equal pay, available at https://action4equalityscotland.blogspot.com/2017/07/glasgow-and-equal-pay 5.html

Irvine, M. (2017a) Glasgow-Equal pay Update, available at https://action4equalityscotland.blogspot.com/search?q=GMB

Irvine, M. (2017b) Questions for UNISON, available at https://action4equalityscotland.blogspot.com/search?q=UNISON

Irvine, M. (2017c) Golden Goodbyes in Glasgow, available at https://action4equalityscotland.blogspot.com/2017/12/golden-goodbyes-in-glasgow.html

Irvine, M. (2017d) Glasgow MSPs and MPs, available at http://action4equalityscotland.blogspot.com/2017/03/glasgow-msps-and-mps.html 
Johnson, N. and P. Jarley (2004), 'Justice and Union Participation: An Extension and Test of Mobilization Theory', British Journal of Industrial Relations, 42, 3, 543-562.

Kelly, J. (1998), Rethinking Industrial Relations: Mobilization, Collectivism and Long Waves (London: Routledge).

Kelly, J. and V. Badigannavar (2004), 'Union Organizing', in J. Kelly and P. Willman (eds), Union Organization and Activity (London, Routledge) pp. 32-50.

Manky, O. (2018), 'Resource Mobilization and Precarious Workers' Organizations: An Analysis of the Chilean Subcontracted Mineworkers Unions', Work, Employment and Society, 32, 3, 581-598.

Markowitz, L. (2000), Worker Activism After Successful Union Organizing (New York, Taylor and Francis).

Murphy, C. and T. Turner (2014), 'Organising Non-Standard Workers: Union Recruitment in the Irish Care Sector', Industrial relations Journal, 45, 5, 373-388.

O'Reilly, D. and M. Reed (2010), 'Leaderism: An Evolution of Managerialism in the UK Public Service Reforms', Public Administration, 88, 4, 960-978.

Parsons, E. and V. Priola (2013), 'Agents for Change and Changed Agents: The MicroPolitics of Change and Feminism in the Academy', Gender, Work and Organization, 20, 5, 580-598.

Paterson, S. and Stewart, C. (2018) Delight as Glasgow City Council votes to end longrunning equal pay battle, Evening Times, $17^{\text {th }}$ January, available at https://www.eveningtimes.co.uk/news/15847638.Delight_as_Glasgow_City_Council_votes_t o_end_long-running_equal_pay_battle/

People Management (2017) Court victory for thousands of women in Glasgow equal pay battle, available at https://www.peoplemanagement.co.uk/news/articles/equal-pay-battlewomen-victory-glasgow

Perkins, S. and G. White (2010), 'Modernising Pay in the UK Public Services: Trends and Implications', Human Resource Management Journal, 20, 3, 244-257.

Poling, S. (2005), ‘Only Women's Work', BBC Frontline Scotland, BBC One.

Ramsay, H. (1977), 'Cycles of Control: Worker Participation in Sociological and Historical Perspective', Sociology, 11, 3, 481-506.

Ridley, Y (2015) How women in Scotland have been failed by union hypocrisy on equal pay, Common Space, $1^{\text {st }}$ September, available at https://www.commonspace.scot/articles/2307/yvonne-ridley-how-women-scotland-havebeen-failed-union-hypocrisy-equal-pay

Robinson, A. (2018), ‘The Trouble with Women', 14 June.

Scottish Government (2009) Local Government and Communities Committee, Official Report, 11 March, available at 
Simms, M. (2007) 'Managed Activism: Two Union Organizing Campaigns in the Not-forProfit Sector', Industrial Relations Journal, 38, 2, 119-135.

Taylor, P. and P. Bain (2003), 'Call Centre Organizing in Adversity', in G. Gall (ed), op cit, pp.153-172.

The Herald (2005) Women council staff win up to $£ 9000$ each in equal pay deal as Glasgow agrees to $£ 40 \mathrm{~m}$ in compensation, The Herald, $5^{\text {th }}$ October, available at https://www.heraldscotland.com/news/12478496.women-council-staff-win-up-to-gbp9000each-in-equal-pay-deal-glasgow-agrees-to-gbp40m-in-compensation/

The Herald (2007) Equal pay compensation claims cost $£ 117 \mathrm{~m} \ldots$ and counting, The Herald, $17^{\text {th }}$ March, available at https://www.heraldscotland.com/news/12766428.equal-paycompensation-claims-cost-pound $117 \mathrm{~m}$-and-counting/

The Journal (2005) Council offers free legal advice to staff, The Journal of the Law Society of Scotland, $1^{\text {st }}$ November, available at http://www.journalonline.co.uk/News/1002413.aspx\#.W9BLG3tKh6u

Tilly, C. (1977) From Mobilization to Revolution, Centre for Research on Social Organisation Working Paper No. 156 (University of Michigan).

Tomlinson, J. (2005), 'Women's Attitudes Towards Trade Unions in the UK', Industrial Relations Journal, 36, 5, 402-418.

UNISON (2009) Action 4 Equality Scotland Issues Apology to UNISON Member, available at https://www.unison.org.uk/news/article/2009/06/action-4-equality-scotland-issues-apologyto-unison-member/

Walters, S. (2002), 'Female Part Time Workers' Attitudes to Trade Unions in Britain', Journal of Industrial Relations, 40, 1, 49-68.

Wood, A. (2015), 'Networks of Injustice and Worker Mobilization at Walmart', Industrial Relations Journal, 46, 4, 259-274. 